\title{
Virus persistence in pig herds led to successive reassortment events between swine and human influenza A viruses, resulting in the emergence of a novel triple-reassortant swine influenza virus
}

\author{
Amélie Chastagner ${ }^{1,4}$, Emilie Bonin 1,4,7 ${ }^{1, C h r i s t e l l e ~ F a b l e t ~}{ }^{2,4}$, Stéphane Quéguiner ${ }^{1,4}$, Edouard Hirchaud ${ }^{3,4}$, \\ Pierrick Lucas ${ }^{3,4}$, Stéphane Gorin ${ }^{1,4}$, Nicolas Barbier ${ }^{1,4}$, Véronique Béven ${ }^{3,4}$, Emmanuel Garin 5,6,8, \\ Yannick Blanchard ${ }^{3,4}$, Nicolas Rose ${ }^{2,4}$, Séverine Hervé ${ }^{1,4}$ and Gaëlle Simon ${ }^{1,4^{*}}$ (i)
}

\begin{abstract}
This report describes the detection of a triple reassortant swine influenza A virus of $\mathrm{H}_{2}{ }_{\mathrm{av}} \mathrm{N} 2$ subtype. It evolved from an avian-like swine $\mathrm{H}_{\mathrm{av}} \mathrm{N} 1$ that first acquired the $\mathrm{N} 2$ segment from a seasonal H3N2, then the M segment from a 2009 pandemic $\mathrm{H} 1 \mathrm{N1}$, in two reassortments estimated to have occurred 10 years apart. This study illustrates how recurrent influenza infections increase the co-infection risk and facilitate evolutionary jumps by successive gene exchanges. It recalls the importance of appropriate biosecurity measures inside holdings to limit virus persistence and interspecies transmissions, which both contribute to the emergence of new potentially zoonotic viruses.
\end{abstract}

\section{Introduction, methods, and results}

Influenza A viruses (IAVs) are pathogens with high impact on public and animal health. Several mechanisms, including high mutation rate, reassortment of genes and host switch, are responsible for the genetic and antigenic evolution of IAVs [1]. The surveillance of swine IAVs (swIAVs) is of major concern to study IAV evolution in pigs and assess interspecies transmission risks. Indeed, pig could serve as an intermediate host for the adaptation of avian influenza viruses to mammals, as well as a host for the generation of reassortant viruses with genes of different origins, due to their susceptibility to both avian and human IAVs [1,2]. Since the 2009 pandemic, four swIAVs lineages have become enzootic in the European pig population, i.e., avian-like swine $\mathrm{H} 1 \mathrm{~N} 1\left(\mathrm{H} 1_{\mathrm{av}} \mathrm{N} 1\right)$,

\footnotetext{
*Correspondence: gaelle.simon@anses.fr

1 Swine Virology Immunology Unit, Ploufragan-Plouzané-Niort

Laboratory, ANSES, BP53, 22440 Ploufragan, France

Full list of author information is available at the end of the article
}

pandemic-like swine H1N1 (H1N1pdm), human-like reassortant swine $\mathrm{H} 1 \mathrm{~N} 2\left(\mathrm{H}_{\mathrm{hu}} \mathrm{N} 2\right)$ and human-like reassortant swine H3N2 (H3N2), with relative frequencies varying from country to country $[3,4]$. Reassortant viruses either with genes from different enzootic swIAVs or with gene(s) from enzootic swIAV combined to gene(s) from human seasonal IAV are occasionally detected in pigs $[4,5]$. Whereas they are most of the time sporadically identified, such reassortants can adapt to the species and examples of novel circulating swIAVs have been evidenced locally in the recent years, such as in Denmark, Germany and United-Kingdom [4]. Recurrent influenza, i.e., swIAV infection in each successive batch of pigs reared, was suggested to be associated to swIAV enzootic persistence at the herd level, a situation that would favor co-circulation of different swIAV subtypes and/or coinfection events with enzootic swIAVs and human IAVs, both situations being a prerequisite to the emergence of novel reassortant viruses $[6,7]$. 
This study reports the detection in France of a novel triple reassortant $\mathrm{H} 1_{\mathrm{av}} \mathrm{N} 2$ virus following two reassortment events that took place probably 10 years apart. This new reassortant has evolved from a swine $\mathrm{H} 1_{\mathrm{av}} \mathrm{N} 1$ virus that acquired, first the $\mathrm{N} 2$ segment of a seasonal human H3N2 virus, then the $M$ segment of a H1N1pdm virus.

\section{Case description and preliminary investigations for IAV infections}

In February 2010, epidemiological and microbiological investigations were implemented in a farrow-to-finish pig herd (farm A) located in the Indre-et-Loire administrative department (\#37) in France, due to severe and repeated outbreaks of porcine respiratory disease complex. At that time, the herd counted 2100 sows and was managed with a 1-week batch interval. It purchased its breeding stock, and replacement gilts were housed in an acclimatization barn located on-site. First IAV infection was evidenced through serological analyses on fattening pigs. Hemagglutination inhibition (HI) assays, performed using a reference panel of antigens representative for European swine IAVs [3], revealed the presence of antibodies directed against the hemagglutinin (HA) of $\mathrm{H}_{\mathrm{av}} \mathrm{N} 1$ viruses known to circulate in French pig herds since the early 80' [4]. In September 2011, after several months during which cough was reported in many batches of pigs from all physiological stages, the IAV genome was detected by M-gene RT-qPCR [8] in nasal swab supernatants taken on piglets of 7-8 weeks of age and exhibiting influenza-like illness (ILI) clinical signs, i.e., hyperthermia, apathy, dyspnea, sneezing and coughing for no more than 2-3 days for individual animals. Molecular subtyping using RT-qPCRs specifically designed for the amplification of the HA- and the neuraminidase (NA-) encoding genes from the different swIAVs circulating in France and in Europe [8] identified an HA gene from the $\mathrm{H} 1_{\mathrm{av}} \mathrm{N} 1$ lineage and a NA gene of N2 subtype, demonstrating an infection with a $\mathrm{H}_{1}{ }_{\mathrm{av}} \mathrm{N} 2$ reassortant virus. In April 2012, a vaccination program was set up, consisting in the injection of sows at each breeding cycle, with one dose $(2 \mathrm{~mL} / \mathrm{pig})$ of adjuvanted-inactivated trivalent $\left(\mathrm{H}_{\mathrm{av}} \mathrm{N} 1\right.$, $\mathrm{H} 3 \mathrm{~N} 2, \mathrm{H} 1_{\text {hu }} \mathrm{N} 2$ ) vaccine Gripovac $^{\circledR} 3$ (Mérial, Lyon, France). However, the herd seemed to remain permanently infected as recurrent respiratory outbreaks continued to be reported by the farmer in successive batches of pigs, especially at the nursery stage. In October 2012, virus isolation from nasal swab supernatants taken on 7 week-old piglets led to the identification of a $\mathrm{H} 1{ }_{\mathrm{av}} \mathrm{N} 2$ reassortant virus again. In 2013, the vaccination program was limited to gilts, with two injections (Gripovac ${ }^{\circledR} 3$ ) 3 weeks apart upon arrival in quarantine, followed by a vaccination booster 3 weeks before farrowing. In 2014, several batches of gilts were imported from Denmark and the number of sows increased to 2600. From March 2015 , the herd opted for self-replacement of the breeding stock, and still ensuring quarantine of young breeding animals in the acclimatization building. However, the herd still experienced recurrent respiratory outbreaks, while the gilt vaccination program continued using the Respiporc $\mathrm{FLU}^{\circledR} 3$ vaccine (formerly Gripovac ${ }^{\circledR} 3$; IDTBiologika, Dessau-Rosslau, Germany). In May 2016, the IAV genome was detected in nasal swabs taken on 7-week-old piglets with ILI of strong intensity, i.e., lasting longer than 4 days and including coughing fits. For the third time, molecular subtyping indicated an infection with a $\mathrm{H} 1_{\text {av }} \mathrm{N} 2$ reassortant virus.

\section{Genetic characterization of the three $\mathrm{H} 1{ }_{\mathrm{av}} \mathrm{N} 2$ reassortant viruses successively identified in 2011, 2012 and 2016 in farm $A$}

The $\mathrm{H} 1_{\mathrm{av}} \mathrm{N} 2$ virus detected in 2011 and named $\mathrm{A} /$ Sw/France/37-110543/2011 did not propagate in cell culture or embryonated chicken eggs, probably due to limited amounts of virus particles in the 2011 nasal swab supernatants. However, sequencing was performed on viral RNA directly extracted from the swab sample. The $\mathrm{H}_{1}{ }_{\mathrm{av}} \mathrm{N} 2$ viruses detected in 2012 and 2016 were propagated in MDCK cells and named $\mathrm{A} / \mathrm{Sw} /$ France/37-120345/2012 and $\mathrm{A} / \mathrm{Sw} /$ France/37-160178/2016, respectively. Whole genome sequences of these three virus strains were obtained by next generation sequencing (NGS) on an Ion Proton instrument (Life Technologies) as previously described [9]. The HA segments were confirmed to belong to the $\mathrm{H} 1_{\mathrm{av}}$ lineage (clade 1C.2.1, [10]) being closely similar to those of enzootic $\mathrm{H}_{\mathrm{av}} \mathrm{N} 1$ strains circulating in the French pig population (Figure 1A). By contrast, phylogenetic analyses showed that NA genes did not originate from enzootic swIAVs of the European $\mathrm{H}_{1}{ }_{\mathrm{hu}} \mathrm{N} 2$ or H3N2 lineages, but were closely related (97.09\% identity) to $\mathrm{N} 2$ genes of seasonal human $\mathrm{H} 3 \mathrm{~N} 2$ viruses isolated in 2003 (Figure 1B). The time of the most recent common ancestor (TMRCA) was estimated to 2003.528 [2003.094; 2003.801] using BEAST software, leading to the hypothesis that these reassortants originated from a co-infection with a $\mathrm{H} 1_{\mathrm{av}} \mathrm{N} 1$ swIAV and a 2003 human H3N2.

All internal genes of the three strains were shown to be very similar with each other and closely related to internal genes from $\mathrm{H}_{1}{ }_{\mathrm{av}} \mathrm{N} 1$ and $\mathrm{H} 1_{\mathrm{hu}} \mathrm{N} 2$ viruses circulating in France, except the M-encoding gene of $\mathrm{A} / \mathrm{Sw} /$ France/37-160178/2016 that belonged to the H1N1pdm lineage (Figures $1 \mathrm{C}$ and D and Additional file 1). The phylogenetic analysis indicated that this Mpdm segment was highly similar to that of H1N1pdm strains isolated in humans or pigs in 2013-2014 (TMRCA $=2013.863$ [2013.492; 2014.216]), suggesting that a reassortment 
A

0.05

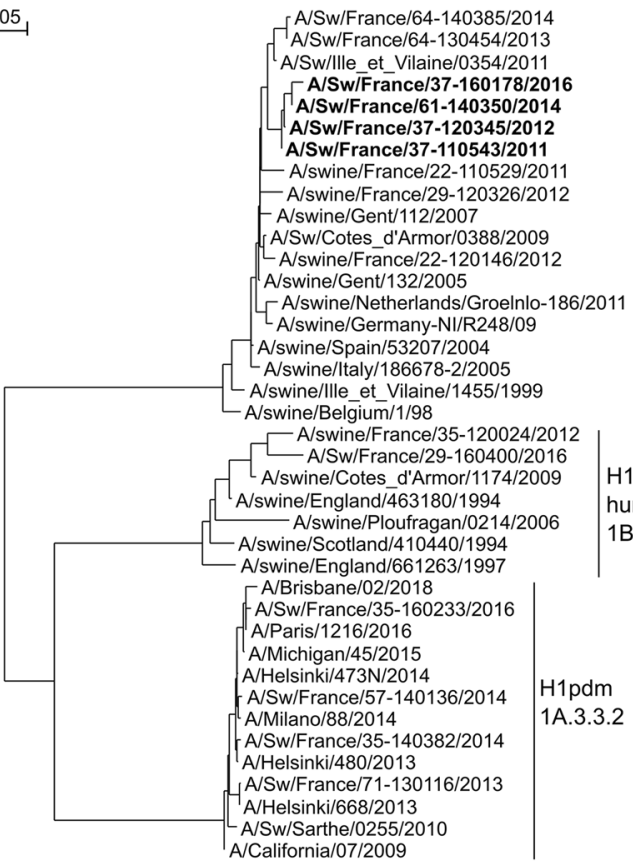

C

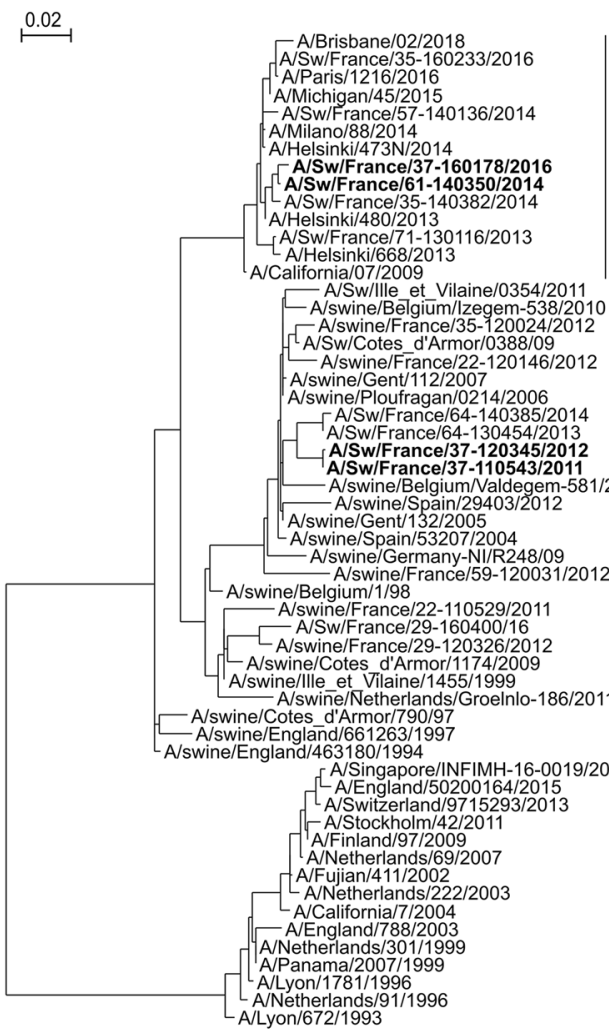

B

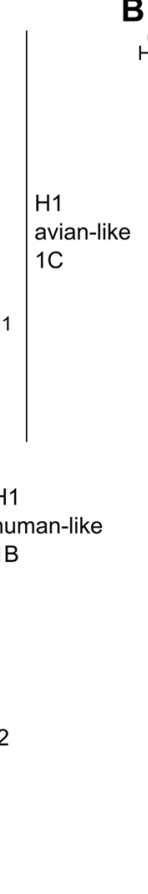

$\stackrel{0.02}{\longmapsto}$

A/Singapore/INFIMH-16-0019/2016 A/England/50200164/2015 A/Stockholm/42/2011 A/Finland/97/2009

A/Netherlands/69/2007

A/California/7/2004

[A/Fujian/411/2002

A/Netherlands/222/2003 A/Sw/France/37-160178/2016 A/Sw/France/61-140350/2014 A/Sw/France/37-120345/2012 A/England/788/2003

A/Denmark/84/2003

A/New_York/55/01

A/New York/55/01
A/Netherlands/88/2003

A/Panama/2007/1999

A/Netherlands/301/1990

- A/Netherlands/91/1996

A/Lyon/1781/1996
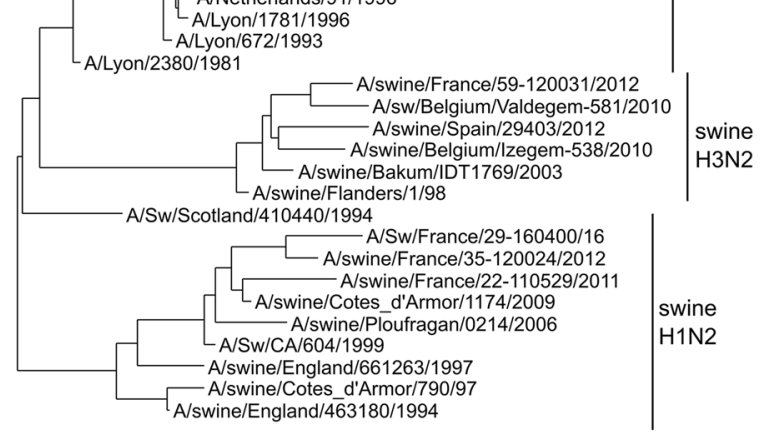

swine

H1N2

Human

H3N2 3N2

D

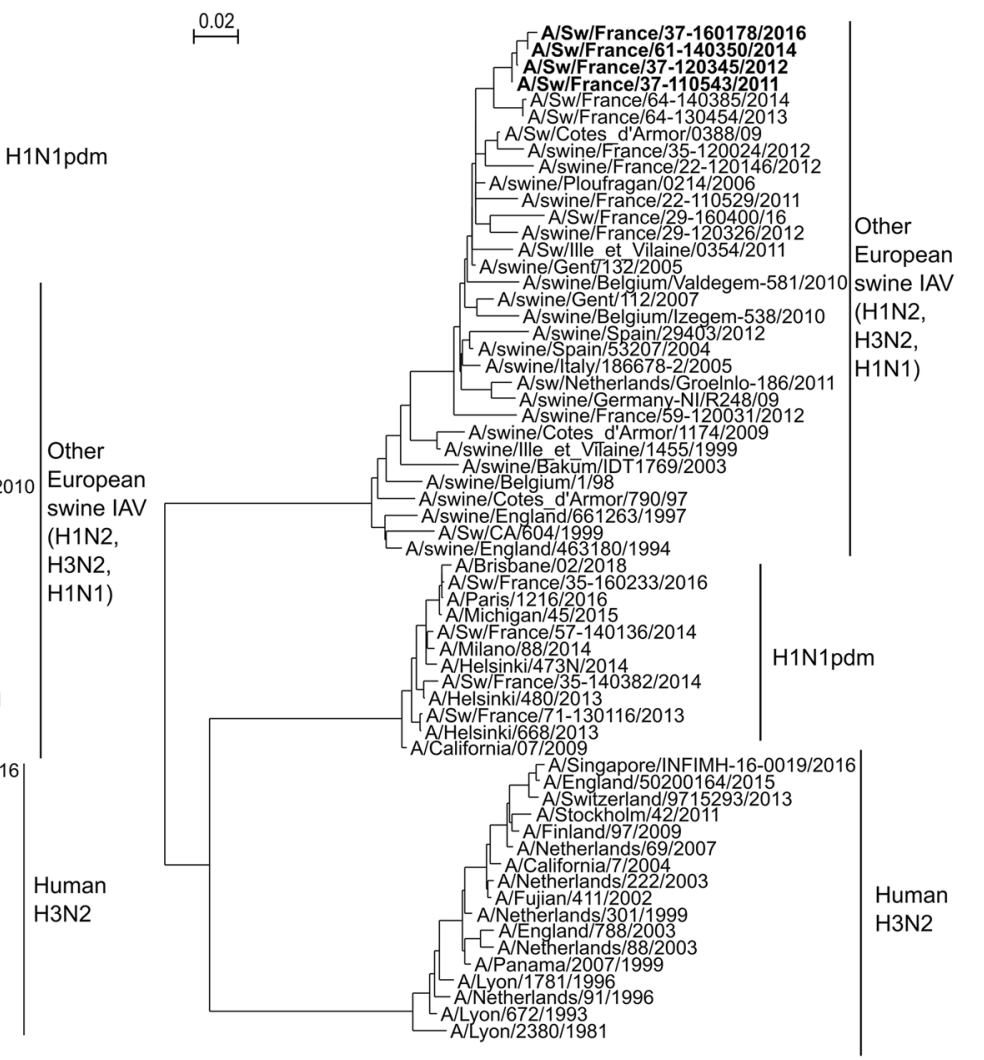

Figure 1 Unrooted phylogenetic trees of European swine and human influenza A viruses. A HA segment; B NA segment; $\mathbf{C}$ M segment; D Concatenation of the five other internal segments (PB2, PB1, PA, NP, NS). Phylogenetic trees were built with Seaview by maximum likelihood with the nucleotide substitution model $\mathrm{HKY}+\mathrm{G}$. The $\mathrm{H}_{\mathrm{av}} \mathrm{N} 2$ strains described in this study are indicated in bold. Only $\mathrm{H} 1$ and $\mathrm{N} 2$ subtypes were included in HA (A) and NA (B) trees, respectively. 
between the $\mathrm{H} 11_{\mathrm{av}} \mathrm{N} 2$ reassortant virus and a $\mathrm{H} 1 \mathrm{~N} 1 \mathrm{pdm}$ virus took place in these years.

\section{Other $\mathrm{H} 1_{a v} \mathrm{~N} 2$ reassortant viruses identified in France from 2010 to 2018}

From February 2010 to December 2018, 18 other $\mathrm{H} 1_{\text {av }} \mathrm{N} 2$ swIAVs were identified in French pig herds, leading the proportion of such reassortants to $2.22 \%$ (21/944) among the swIAVs identified in France thanks to diagnostic requests including those from Résavip, the national surveillance network for swIAV [11]. Thirteen of them were isolated on MDCK cells and sequence analyses revealed that only one harbored a N2 gene of human origin. This isolate, named A/Sw/France/61-140350/2014, was detected in June 2014 in 7-week-old piglets affected by ILI of normal intensity, in a post-weaning-finishing farm (farm B) located in the Orne administrative department (\#61). Interestingly, it presented exactly the same genotype than A/Sw/France/37-160178/2016, with a 2003 seasonal N2 gene, a Mpdm segment from 2013 to 2014 and other genes from the $\mathrm{H}_{1}$ av $\mathrm{N} 1$ lineage (Figure 1 and Additional file 1). Both viruses were 99.98-99.99\% identical on all genes (data not shown). All other $\mathrm{H} 1_{\mathrm{av}} \mathrm{N} 2$ viruses shared $\mathrm{H} 1_{\mathrm{av}}, \mathrm{N} 2$ and internal genes from swine lineages (data not shown).

\section{Amino acid sequences and antigenic characterization of $\mathrm{H} 1_{\text {av }} \mathrm{N} 2$ reassortant viruses}

At the nucleotide level, phylogenetic analyses revealed that $\mathrm{N} 2$ genes of reassortant $\mathrm{H} 1{ }_{\mathrm{av}} \mathrm{N} 2$ strains were closely related to those of 2003 human strains that did not derive from A/Fujan/411/2002(H3N2) as most of other H3N2 human strains isolated in 2003 worldwide but from the previous strain A/New York/55/01(H3N2) (Figure 1). Thus, deduced NA amino acid sequences of the four $\mathrm{H} 1_{\mathrm{av}} \mathrm{N} 2$ reassortants were compared to that of $\mathrm{A} /$ New York/55/01(H3N2) as a reference strain (Table 1). Alignments showed that all N2 glycoproteins exhibited several mutations in common, such as NA-K221N, NAN329K and NA-S372L that, according to BII FluSurver, were described to be involved in antigenic drift of H3N2 human strains (Table 1). Looking for the occurrence of these three mutations in swine and human IAV N2 sequences retrieved from the Influenza Research Database, it appeared they were rarely observed in human strains from 2000 to 2005 regardless their genogroup (Table 1). By contrast, mutation S372L was observed in the majority of both recent human and swine strains, i.e., isolated from 2011 to 2016 (Table 1). Changing in NA-S372 residue was suspected to reduce the hemadsorption activity of human $\mathrm{H} 3 \mathrm{~N} 2$ and $\mathrm{H} 2 \mathrm{~N} 2$ strains [12, 13]. Interestingly, NA-K $221 \mathrm{~N}$ and two other mutations, i.e., NA-Y40H, and NA-V263I, were almost exclusively associated to swine but not human strains in the recent years 2011-2016 (Table 1) and could reflect divergent host-specific evolutions and/or swine host adaptation following inter-species transmission.

Comparison of $\mathrm{H}_{\mathrm{av}}$ protein sequences of $\mathrm{H}_{\mathrm{av}} \mathrm{N} 2$ strains to the HA sequence of the French $\mathrm{H}_{2}{ }_{\mathrm{av}} \mathrm{N} 1$ ancestral strain $\mathrm{A} / \mathrm{Sw} /$ Cotes d'Armor/0388/09(H1 $\left.{ }_{\mathrm{av}} \mathrm{N} 1\right)$ allowed identifying several mutations that were fixed on the $\mathrm{H} 1_{\mathrm{av}} \mathrm{N} 2$ reassortants (Table 2). According to BII FluSurver, many of them were reported to affect antigenic sites and suspected to be involved in antigenic drift (Table 2). Interestingly, the HA-G391R mutation into the HA2 subunit was never reported in swIAVs before, whereas described to increase the virulence of a human H1N1 prototype strain in MDCK cells and mouse lung [14]. More broadly, comparison of $\mathrm{H} 1_{\mathrm{av}}$ amino acid sequences to those of other $\mathrm{H} 1_{\mathrm{av}} \mathrm{N} 1$ and $\mathrm{H} 1_{\mathrm{av}} \mathrm{N} 2$ swIAVs did not permit the identification of mutations that would be specifically related to a maintenance of the HA/NA balance following the acquisition of a N2-encoding gene of human but not swine origin (data not shown).

In order to further characterize the reassortants at the antigenic level, they were propagated on chicken embryonated eggs to be tested in HI tests using turkey's red blood cells according to standard protocols [15]. Strains A/Sw/ France/37-120345/2012, A/Sw/France/61-140350/2014 and $\mathrm{A} / \mathrm{Sw} /$ France/37-160178/2016 were incubated with porcine hyperimmune sera containing antibodies directed against strains representative for the European enzootic swIAVs (Table 3). High HI titers (160-640) were obtained with antiserum to the $\mathrm{H} 1_{\text {av }} \mathrm{N} 1$ reference strain, without any evidence of greater antigenic distance than reference strains (Table 3 ) or other contemporary $\mathrm{H} 1_{\mathrm{av}} \mathrm{N} 1$ strains (data not shown). Some cross-reactivity (HI titers 20-40) with antibodies directed against H1N1pdm reference strain was measured, as previously described for parental $\mathrm{H} 1_{\mathrm{av}} \mathrm{N} 1$ viruses [16].

\section{Discussion}

In this study, we evidenced two successive reassortment events that probably occurred 10 years apart, i.e., around 2003 and 2013, respectively. Thus, a swine $\mathrm{H} 1_{\mathrm{av}} \mathrm{N} 1$ virus first acquired a N2 segment from a contemporary human H3N2 virus, and then a $M$ segment from a H1N1pdm strain.

The human N2 incorporation into a French swine $\mathrm{H} 1_{\mathrm{av}} \mathrm{N} 1$ strain certainly resulted from a human-to-swine transmission of a human $\mathrm{H} 3 \mathrm{~N} 2$ virus around 2003, as similar N2 sequences were never described in European swine strains before. However, the origin of the parental human strain remains uncertain, as the few N2 sequences of 2000-2005 French H3N2 strains available in public databases do not belong to the $\mathrm{A} / \mathrm{New}$ 
Table 1 Amino acid differences in NA protein sequences of the $\mathrm{H}_{{ }_{\mathrm{av}}} \mathrm{N} 2$ viruses described in this study as compared to NA residues in reference strain $\mathrm{A} / \mathrm{New}$ York/55/01 (NY/55/01)

\begin{tabular}{|c|c|c|c|c|c|c|c|c|c|}
\hline \multicolumn{5}{|c|}{$\begin{array}{l}\text { Amino acid changes in swine } \mathrm{H}_{1} \text { av } \mathrm{N} 2 \\
\text { strains }\end{array}$} & \multirow[t]{2}{*}{ Reported effects ${ }^{b}$} & \multicolumn{4}{|c|}{$\begin{array}{l}\text { Frequency of amino acid change in human or swine strains } \\
\text { available in IRD }\end{array}$} \\
\hline$N Y / 55 / 01$ & A-11 & A-12 & B-14 & A-16 & & $\begin{array}{l}\text { Human } \\
1957-1980 \\
(N=323)\end{array}$ & $\begin{array}{l}\text { Human } \\
2000-2005 \\
(N=1921)\end{array}$ & $\begin{array}{l}\text { Human } \\
2011-2016 \\
(N=8108)\end{array}$ & $\begin{array}{l}\text { Swine } \\
2011-2016 \\
(N=4397)\end{array}$ \\
\hline Т19 & A & A & A & A & - & 0.31 & 6.98 & 0.04 & 4.82 \\
\hline L23 & $F$ & $\mathrm{~F}$ & $\mathrm{~F}$ & $\mathrm{~F}$ & - & 0.31 & 47.11 & 98.87 & 5.53 \\
\hline A27 & V & V & V & V & - & 0 & 0.57 & 0.037 & 0.32 \\
\hline Y40 & $\mathrm{H}$ & $\mathrm{H}$ & $\mathrm{H}$ & $\mathrm{H}$ & - & 39.01 & 22.12 & 0.54 & 76.64 \\
\hline N47 & $\mathrm{T}$ & $\mathrm{T}$ & T & I & - & 0 & 0 & 0 & 1.07 \\
\hline A56 & $\mathrm{T}$ & । & । & I & - & $2.48(\mathrm{~T}) / 97.21(\mathrm{I})$ & $97.19(\mathrm{~T}) / 0.10(\mathrm{I})$ & $99.68(\mathrm{~T}) / 0.19(\mathrm{I})$ & $93.43(\mathrm{~T}) / 4.21(\mathrm{I})$ \\
\hline V66 & - & - & M & M & - & 0.31 & 0 & 0.11 & 0.86 \\
\hline E199 & - & - & - & K & - & 80.80 & 61.84 & 99.46 & 37.89 \\
\hline K221 & $\mathrm{N}$ & N & $\mathrm{N}$ & $\mathrm{N}$ & Antigenic drift/escape mutant & 99.69 & 1.04 & 0.78 & 81.49 \\
\hline K249 & $\mathrm{R}$ & R & $\mathrm{R}$ & $\mathrm{R}$ & - & 97.83 & 1.09 & 0.47 & 12.05 \\
\hline 1254 & V & V & V & V & - & 0.31 & 0 & 0.30 & 1.02 \\
\hline V263 & - & - & । & । & - & 0.31 & 2.97 & 0.60 & 57.90 \\
\hline S271 & $\mathrm{N}$ & $\mathrm{N}$ & $\mathrm{N}$ & $\mathrm{N}$ & - & 0 & 0.10 & 0.16 & 0.23 \\
\hline Q273 & $\mathrm{H}$ & $\mathrm{H}$ & $\mathrm{H}$ & $\mathrm{H}$ & - & 0 & 0.05 & 0.01 & 0.07 \\
\hline N329 & K & K & K & K & $\begin{array}{l}\text { Antigenic drift/escape mutant, } \\
\text { removes a potential N-glycosyla- } \\
\text { tion site }\end{array}$ & 0 & 0.05 & 0.78 & 0.18 \\
\hline H336 & $\mathrm{R}$ & - & - & - & - & 0 & 0.05 & 0.04 & 0.45 \\
\hline D339 & G & G & G & G & - & 0 & 0.21 & 0.37 & 0.18 \\
\hline N358 & $\mathrm{H}$ & $\mathrm{H}$ & $\mathrm{H}$ & $\mathrm{H}$ & - & 0 & 0 & 0 & 0.07 \\
\hline S372 & L & L & L & $L$ & Antigenic drift/escape mutant & 0.31 & 2.03 & 98.00 & 81.74 \\
\hline G401 & - & - & $\mathrm{D}$ & $\mathrm{D}$ & - & 70.59 & 2.76 & 0.42 & 10.98 \\
\hline E432 & - & - & - & K & Antigenic drift/escape mutant & 0 & 0.16 & 0.15 & 1.55 \\
\hline 1469 & M & M & M & M & - & 0 & 0.10 & 0.04 & 3.78 \\
\hline
\end{tabular}

Swine $\mathrm{H} 1{ }_{\text {av }} \mathrm{N} 2$ reassortants were abbreviated as following: A-11 for A/Sw/France/37-110543/2011 [Farm A], A-12 for A/Sw/France/37-120345/2012 [Farm A], B-14 for A/ Sw/France/61-140350/2014 [Farm B] and A-16 for A/Sw/France/37-160178/2016 [Farm A].

a Frequency based on the occurrence of the mutated residue in N2 proteins from human or swine IAV strains whose sequences available in the Influenza Research Database on April, $16^{\text {th }} 2019$.

b According to the Bll FluSurver.

York/55/01(H3N2) lineage. The closest N2 genes that were retrieved belong to 2003 human $\mathrm{H} 3 \mathrm{~N} 2$ viruses isolated in England and Denmark, the latest originating from a reassortment between A/New York/55/01(H3N2) and A/Fujan/411/2002(H3N2) [17]. This first reassortant could have been introduced in toto in farm A between 2003 and 2010-2011, from another previously infected herd, or could have been generated in farm A itself thanks to a co-infection event. In any case, it is likely that this virus was maintained in farm A for some years, probably thanks to recurrent outbreaks that were shown to be associated with endemic persistence of swIAVs at the herd level [6]. These recurrent infections would be favored by herd management in batches, which introduces naïve individuals regularly in the herd [6]. Sow vaccination before farrowing was shown to reduce piglet susceptibility to swIAVs, thanks to maternally-derived antibodies. However, they did not prevent virus excretion by infected animals and extended virus spreading at the herd scale, a phenomenon that would also contribute to virus persistence on farms $[18,19]$. It has also to be noted that other HxN2 swIAVs with $\mathrm{N} 2$ gene of human origin were previously reported to circulate in American, Italian and Danish herds for several years, confirming that this kind of reassortant virus could persist in swine populations [5, 20, 21].

Based on genetic similarity, it seemed unlikely that the triple reassortant virus was introduced in toto thanks to importations. The Mpdm segment acquired by the $\mathrm{H} 1_{\mathrm{av}} \mathrm{N} 2$ virus during the second reassortment could have 
Table 2 Amino acid differences in HA protein sequences of the $\mathrm{H}_{1}{ }_{\mathrm{av}} \mathrm{N} 2$ viruses described in this study as compared to $\mathrm{HA}$ residues in reference strain A/Sw/Cotes d'Armor/0388/09 (CA/388/09)

\begin{tabular}{|c|c|c|c|c|c|}
\hline$C A / 388 / 09^{a}$ & A-11 & A-12 & B-14 & A-16 & Reported effect ${ }^{c}$ \\
\hline V14 & $A^{b}$ & $A^{b}$ & $A^{b}$ & $A^{b}$ & - \\
\hline V22 & । & 1 & । & I & - \\
\hline S53 & N & $\mathrm{N}$ & N & N & Antigenic drift/escape mutant \\
\hline Q68 & $\mathrm{H}$ & $\mathrm{H}$ & $\mathrm{H}$ & $\mathrm{H}$ & - \\
\hline V74 & - & - & । & । & - \\
\hline L86 & S & S & $P$ & $P$ & - \\
\hline L88 & - & - & - & $P$ & Antigenic drift/escape mutant \\
\hline S154 & $P$ & P & $P$ & $P$ & Antigenic drift/escape mutant \\
\hline S156 & - & - & L & L & Antigenic drift/escape mutant \\
\hline G172 & - & - & - & R & Antigenic drift/escape mutant and other \\
\hline L178 & - & - & - & । & - \\
\hline K186 & - & - & $\mathrm{R}$ & $\mathrm{R}$ & - \\
\hline G187 & - & - & - & E & - \\
\hline 1192 & $V^{b}$ & $V^{b}$ & $V^{b}$ & $V^{b}$ & - \\
\hline D202 & - & - & V & V & - \\
\hline T249 & । & । & । & । & - \\
\hline $\mathrm{H} 270$ & - & - & - & Y & - \\
\hline G277 & S & S & S & S & $\begin{array}{l}\text { Creates a new potential N-glycosylation } \\
\text { site at position } 275\end{array}$ \\
\hline V282 & $1^{b}$ & $\mathrm{I}^{\mathrm{b}}$ & $1^{b}$ & $1^{b}$ & - \\
\hline D286 & $N$ & $N$ & N & N & - \\
\hline $\mathrm{H} 288$ & - & $N$ & $N$ & $N$ & - \\
\hline Y300 & $H^{b}$ & $\mathrm{H}^{\mathrm{b}}$ & $H^{b}$ & $H^{b}$ & - \\
\hline K304 & - & - & N & N & - \\
\hline S305 & G & G & G & - & - \\
\hline N306 & S & $S$ & S & S & - \\
\hline E319 & - & K & - & - & - \\
\hline G391 & $\mathrm{R}$ & $\mathrm{R}$ & R & R & Virulence \\
\hline S393 & $N$ & $\mathrm{~N}$ & N & N & - \\
\hline 1444 & - & - & V & V & - \\
\hline K460 & $\mathrm{R}$ & $\mathrm{R}$ & R & R & - \\
\hline E516 & - & - & - & K & - \\
\hline
\end{tabular}

Swine $\mathrm{H}_{\text {av }} \mathrm{N} 2$ reassortants were abbreviated A-11 for A/Sw/France/37-110543/2011 [Farm A], A-12 for A/Sw/France/37-120345/2012 [Farm A], B-14 for A/Sw/ France/61-140350/2014 [Farm B] and A-16 for A/Sw/France/37-160178/2016 [Farm A].

a $\mathrm{CA} / 388 / 09$ is a reference strain representative of European swine avian-like $\mathrm{H}{ }_{\mathrm{av}} \mathrm{Ny}$ viruses belonging to the HA clade 1C.2.1 (after Anderson et al. [10]).

${ }^{b}$ Residue fixed in French swIAV strains of avian-like $\mathrm{H} 1\left(\mathrm{H}_{\mathrm{av}}\right)$ lineage since 2000'.

c According to the Bll FluSurver.

been provided by a H1N1pdm virus, either subsequent to a human-to-swine transmission during the 2013-2014 seasonal epidemic or from a swine-to-swine transmission as this virus also circulates in pigs in France and other European countries $[3,9,22]$. What is obvious is that the Mpdm gene did not originate from a H1N1pdm strain belonging to the swine-divergent H1N1pdm lineage that was recently identified in pigs in France [9]. However, it cannot be excluded that the Mpdm gene was acquired from another unknown reassortant swIAV containing this genomic segment, as new viruses could be introduced in France thanks to importations of replacement sows for example. The second reassortment event might have occurred in farm A where the first reassortant virus was detected and shown to have persisted for months, possibly years, before. However, the isolation of a similar triple reassortant $\mathrm{H}_{1}{ }_{\mathrm{av}} \mathrm{N} 2$ virus in farm $\mathrm{B}$ in 2014, at the time the second reassortment event was estimated to have occurred, poses questions about where this event took place. Phylogenetic distances between the four 
Table 3 Antigenic cross-reactivity between the novel $\mathrm{H} 1_{\text {av }} \mathrm{N} 2$ reassortant strains and reference strains representative of the European enzootic swIAV lineages

\begin{tabular}{|c|c|c|c|c|}
\hline \multirow[t]{2}{*}{ Virus strain } & \multicolumn{4}{|c|}{ Haemagglutination inhibition titer with hyperimmune sera against: } \\
\hline & $\begin{array}{l}\mathrm{H} 1_{\mathrm{av}} \mathrm{N} 1 \mathrm{~A} / \mathrm{Sw} / \text { Cotes } \\
\mathrm{d}^{\prime} \mathrm{Armor} / 0388 / 09\end{array}$ & $\begin{array}{l}\mathrm{H} 1_{\mathrm{hu}} \mathrm{N} 2 \mathrm{~A} / \mathrm{Sw} / \\
\text { Scotland/410440/94 }\end{array}$ & $\begin{array}{l}\mathrm{H} 3 \mathrm{~N} 2 \mathrm{~A} / \mathrm{Sw} / \\
\text { Flanders/1/98 }\end{array}$ & $\begin{array}{l}\text { H1N1pdm A/Sw/ } \\
\text { Sarthe/0255/10 }\end{array}$ \\
\hline A/Sw/Cotes d'Armor/0388/09 ( $\left.\mathrm{H}_{\mathrm{av}} \mathrm{N} 1\right)$ & 1280 & $<10$ & $<10$ & $<10$ \\
\hline A/Sw/Scotland/410440/94 ( $\left.\mathrm{H}_{\mathrm{hu}} \mathrm{N2}\right)$ & $<10$ & 1280 & 10 & $<10$ \\
\hline A/Sw/Flanders/1/98 (H3N2) & $<10$ & $<10$ & 2560 & $<10$ \\
\hline A/Sw/Sarthe/0255/10 (H1N1pdm) & 40 & $<10$ & $<10$ & 640 \\
\hline A/Sw/France/37-120345/12 ( $\left.\mathrm{H1}_{\mathrm{av}} \mathrm{N} 2\right)$ & 320 & $<10$ & $<10$ & 20 \\
\hline A/Sw/France/61-140350/14 (H1 $\left.1_{\mathrm{av}} \mathrm{N} 2\right)$ & 640 & $<10$ & $<10$ & 40 \\
\hline A/Sw/France/37-160178/16 (H1 $\left.{ }_{\mathrm{av}} \mathrm{N} 2\right)$ & 160 & $<10$ & $<10$ & $<10$ \\
\hline
\end{tabular}

studied strains were congruent, exhibiting genetic evolution rates similar to those reported for swIAV strains across years [23]. This argues in favor of the hypothesis that the triple reassortant strains originated from a single source rather than from two independent reassortment events, which would have resulted in two $\mathrm{H} 1_{\mathrm{av}} \mathrm{N} 2$ triple reassortant strains exhibiting exactly the same gene constellation in the two distant farms. Based on farm A's animal movement reports, any direct epidemiological link could be found between farms A and B, but a recent study showed that the French network of pig movements contributed to the dispersal of pathogens between non linked farms via node holdings that buy and sell pigs for all France [24]. Thus, it makes impossible to affirm that the second reassortment event took place in farm A and then the triple reassortant spread to farm B.

In any cases, the detection of such triple reassortant swIAVs in both farms A and B several years after the initial detection of the unusual parental reassortant virus in farm A gave evidence that reassortments are favored by swIAV persistence in pig herds, by co-circulation of swIAVs of different subtypes, and at last but not least, by transmission of IAVs from humans to pigs. Several examples of H1N1, H1N2 or H3N2 swIAVs containing the Mpdm gene were reported in other countries in Europe, Asia and the United States [4, 25, 26]. In the United States, such reassortants with Mpdm gene have been responsible for human infections at exhibition fairs since 2011 [26]. Whereas subsequent human-to-human transmission seemed limited, such zoonotic infections led WHO to anticipate in selecting vaccine strain candidates [27], taking into account that the Mpdm gene was demonstrated to increase intra- and/or inter-species transmission efficiency of IAV reassortants [28, 29]. Thus, the genomic constellation in addition to the specific mutations fixed incrementally in HA and NA glycoproteins after consecutive infectious cycles in pigs, could make the triple reassortant $\mathrm{H}_{1 \mathrm{av}} \mathrm{N} 2$ swIAVs at an increasing zoonotic risk as compared to parental viruses.

In conclusion, these events illustrate (i) the ability for swIAV to persist in a herd where recurrent influenza is made possible, (ii) the transmission of seasonal human IAV to pigs and (iii) subsequent co-circulations, coinfections and gene exchanges between $\operatorname{swIAV}(\mathrm{s})$ and/ or human IAV, leading to the emergence of novel reassortant swIAV strains. That is why this study recalls the necessity to improve the management of influenza infections inside holdings to avoid swIAV persistence, e.g., by the export of consecutive piglet batches which was identified as the most efficient measure to limit recurrent swIAV infection in farrow-to-finish pig farms [30]. Finally, biosecurity measures should include actions aimed at reducing IAV interspecies transmissions, e.g., to limit the entry of ILI's people, to encourage the use of protective mask and gloves, and to provide pig industry workers the annual influenza vaccine [22].

\section{Supplementary information}

Supplementary information accompanies this paper at https://doi. org/10.1186/s13567-019-0699-y.

Additional file 1. Scheme of genetic reassortment events that led to the detection of $\mathrm{H}_{1}{ }_{\mathrm{av}} \mathrm{N} 2$ viruses in farm $\mathrm{A}$ and farm $\mathrm{B}$ between 2010 and 2016. Donor viruses and viruses that resulted from reassortment events are illustrated above the timeline. The location (farm A or farm B) and year of isolation of the different virus strains that were sequenced in this study are marked with a black triangle below the timeline. The black circle indicate serological investigation and detection of antibodies (Ab) directed against an hemagglutinin from the $\mathrm{H}_{\mathrm{av}}$ lineage.

\section{Acknowledgements}

The authors thank the farmers who gave access to their pig herds. They also thank colleagues from ANSES Epidemiology Health and Welfare Unit for sampling in farm A, as well as the veterinarians and all members of "Résavip", 
the French national network for surveillance of influenza A viruses in pigs, for their implication.

\section{Authors' contributions}

AC and GS interpreted the data and drafted the work. GS coordinated the study. AC performed the phylogenetic and amino acid sequence analyses. $E B, E H$ and PL performed the bio-informatic analyses. SQ, SG, NB and VB performed the lab experiments. CF, EG, NR and SH contributed to swIAV surveillance in France and participated in data collection in farms A and B. YB supervised NGS. All authors read and approved the final manuscript.

\section{Funding}

This study was partially funded by European FP7 project ESNIP3 (no. 259949), by the CoVetLab joint research project 2016 Genetic Characterization of Swine Influenza A Viruses in European Pigs by Next-Generation Sequencing (no. CF0010), and by the European Union's Horizon 2020 program COMPARE (no. 643476).

\section{Availability of data and materials}

All sequences obtained in this study are available in Genbank under Accession numbers KY364173-KY364180; KR700959-KR700966; MN326747-MN326754; MK943742-MK943749. Other datasets generated during and/or analyzed during the current study are available from the corresponding author on reasonable request.

\section{Competing interests}

The authors declare that they have no competing interests.

\section{Author details}

${ }^{1}$ Swine Virology Immunology Unit, Ploufragan-Plouzané-Niort Laboratory, ANSES, BP53, 22440 Ploufragan, France. ${ }^{2}$ Epidemiology, Health and Welfare Unit, Ploufragan-Plouzané-Niort Laboratory, ANSES, BP53, 22440 Ploufragan, France. ${ }^{3}$ Viral Genetic and Biosecurity Unit, Ploufragan-Plouzané-Niort Laboratory, ANSES, BP53, 22440 Ploufragan, France. ${ }^{4}$ Bretagne Loire University, Cité internationale, 1 place Paul Ricoeur, CS 54417, 35044 Rennes, France.

${ }^{5}$ Animal Health Service, Coop de France, 43 Rue Sedaine, 75538 Paris cedex 11, France. ${ }^{6}$ Operational Team, ESA Platform, 31 Avenue Garnier, 69007 Lyon, France. ${ }^{7}$ Present Address: INRA, US 1426, GeT-PlaGe, 24 chemin de borde rouge - Auzeville, CS 52627, 31326 Castanet-Tolosan, France. ${ }^{8}$ Present Address: GDS-France, 37 Rue de Lyon, 75012 Paris, France.

Received: 29 May 2019 Accepted: 23 September 2019 Published online: 07 October 2019

\section{References}

1. Taubenberger JK, Kash JC (2010) Influenza virus evolution, host adaptation and pandemic formation. Cell Host Microbe 7:440-451

2. Ma W, Kahn RE, Richt JA (2008) The pig as a mixing vessel for influenza viruses: human and veterinary implications. J Mol Genet Med 3:158-166

3. Simon G, Larsen LE, Durrwald R, Foni E, Harder T, Van Reeth K, MarkowskaDaniel I, Reid SM, Dan A, Maldonado J, Huovilainen A, Billinis C, Davidson I, Aguero M, Vila T, Herve S, Breum SO, Chiapponi C, Urbaniak K, Kyriakis CS, ESNIP3 Consortium, Brown IH, Loeffen W (2014) European surveillance network for influenza in pigs: surveillance programs, diagnostic tools and Swine influenza virus subtypes identified in 14 European countries from 2010 to 2013. PLoS One 9:e115815

4. Watson SJ, Langat P, Reid SM, Lam TT, Cotten M, Kelly M, Van Reeth K, Qiu Y, Simon G, Bonin E, Foni E, Chiapponi C, Larsen L, Hjulsager C, Markowska-Daniel I, Urbaniak K, Durrwald R, Schlegel M, Huovilainen A, Davidson I, Dan A, Loeffen W, Edwards S, Bublot M, Vila T, Maldonado J, Valls L, ESNIP3 Consortium, Brown IH, Pybus OG, Kellam P (2015) Molecular epidemiology and evolution of influenza viruses circulating within European swine between 2009 and 2013. J Virol 89:9920-9931

5. Nelson MI, Wentworth DE, Culhane MR, Vincent AL, Viboud C, LaPointe MP, Lin X, Holmes EC, Detmer SE (2014) Introductions and evolution of human-origin seasonal influenza a viruses in multinational swine populations. J Virol 88:10110-10119

6. Rose N, Herve S, Eveno E, Barbier N, Eono F, Dorenlor V, Andraud M, Camsusou C, Madec F, Simon G (2013) Dynamics of influenza A virus infections in permanently infected pig farms: evidence of recurrent infections, circulation of several swine influenza viruses and reassortment events. Vet Res 44:72

7. Kyriakis CS, Rose N, Foni E, Maldonado J, Loeffen WL, Madec F, Simon G, Van Reeth K (2013) Influenza A virus infection dynamics in swine farms in Belgium, France, Italy and Spain, 2006-2008. Vet Microbiol 162:543-550

8. Bonin E, Quéguiner S, Woudstra C, Gorin S, Barbier N, Harder TC, Fach P, Hervé S, Simon G (2018) Molecular subtyping of European swine influenza viruses and scaling to high-throughput analysis. Virol J 15:7

9. Chastagner A, Hervé S, Bonin E, Quéguiner S, Hirchaud E, Henritzi D, Béven V, Gorin S, Barbier N, Blanchard Y, Simon G (2018) Spatiotemporal distribution and evolution of the A/H1N1 2009 pandemic influenza virus in pigs in France from 2009 to 2017: identification of a potential swinespecific lineage. J Virol 92:e00988-18

10. Anderson TK, Macken CA, Lewis NS, Scheuermann RH, Van Reeth K, Brown IH, Swenson SL, Simon G, Saito T, Berhane Y, Ciacci-Zanella J, Pereda A, Davis CT, Donis RO, Webby RJ, Vincent AL (2016) A phylogenybased global nomenclature system and automated annotation tool for $\mathrm{H} 1$ hemagglutinin genes from swine influenza A viruses. mSphere 1:e00275-16

11. Garin E, Hervé S, Rose N, Locatelli C, Lecarpentier L, Ngwa-Mbot D, Wendling S, Bournez L, Calavas D, Simon G (2017) National network for surveillance of type A influenza virus in swine (Résavip) — review of operations and surveillance results for 2016. Bull Epid Santé Anim Alim 80:1-5 (in French)

12. Uhlendorff J, Matrosovich T, Klenk HD, Matrosovich M (2009) Functional significance of the hemadsorption activity of influenza virus neuraminidase and its alteration in pandemic viruses. Arch Virol 154:945-957

13. Lin YP, Gregory V, Collins P, Kloess J, Wharton S, Cattle N, Lackenby A, Daniels R, Hay A (2010) Neuraminidase receptor binding variants of human influenza $\mathrm{A}(\mathrm{H} 3 \mathrm{~N} 2)$ viruses resulting from substitution of aspartic acid 151 in the catalytic site: a role in virus attachment? J Virol 84:6769-6781

14. Smeenk CA, Brown EG (1994) The influenza virus variant A/FM/1/47-MA possesses single amino acid replacements in the hemagglutinin, controlling virulence, and in the matrix protein, controlling virulence as well as growth. J Virol 68:530-534

15. OIE (2015) Influenza A virus of swine. In: Health WOfA (ed) Manual of diagnostic tests and vaccines for terrestrial animals 2017, pp 1-14. http:// www.oie.int/en/standard-setting/terrestrial-manual/access-online/

16. Kyriakis CS, Olsen CW, Carman S, Brown IH, Brookes SM, Doorsselaere JV, Reeth KV (2010) Serologic cross-reactivity with pandemic (H1N1) 2009 virus in pigs, Europe. Emerg Infect Dis 16:96-99

17. Bragstad K, Nielsen LP, Fomsgaard A (2008) The evolution of human influenza A viruses from 1999 to 2006: a complete genome study. Virol J $5: 40$

18. Cador C, Herve S, Andraud M, Gorin S, Paboeuf F, Barbier N, Queguiner S, Deblanc C, Simon G, Rose N (2016) Maternally-derived antibodies do not prevent transmission of swine influenza A virus between pigs. Vet Res 47:86

19. Deblanc C, Hervé S, Gorin S, Cador C, Andraud M, Quéguiner S, Barbier N, Paboeuf F, Rose N, Simon G (2018) Maternally-derived antibodies do not inhibit swine influenza virus replication in piglets but decrease excreted virus infectivity and impair post-infectious immune responses. Vet Microbiol 216:142-152

20. Breum SO, Hjulsager CK, Trebbien R, Larsen LE (2013) Influenza a virus with a human-like $n 2$ gene is circulating in pigs. Genome Announc 1:e00712-13

21. Moreno A, Chiapponi C, Boniotti MB, Sozzi E, Foni E, Barbieri I, Zanoni MG, Faccini S, Lelli D, Cordioli P (2012) Genomic characterization of H1N2 swine influenza viruses in Italy. Vet Microbiol 156:265-276

22. Chastagner A, Enouf V, Peroz D, Hervé S, Lucas P, Quéguiner S, Gorin S, Beven V, Behillil S, Leneveu P, Garin E, Blanchard Y, van der Werf S, Simon $G$ (2019) Bidirectional human-swine transmission of seasonal influenza A(H1N1)pdm09 virus in pig herd, France, 2018. Emerg Infect Dis 25:1940-1943

23. Joseph U, Vijaykrishna D, Smith GJD, Su YCF (2018) Adaptive evolution during the establishment of European avian-like H1N1 influenza A virus in swine. Evol Appl 11:534-546

24. Salines M, Andraud M, Rose N (2017) Pig movements in France: designing network models fitting the transmission route of pathogens. PLoS One 12:e0185858 
25. Liu Q, Ma J, Liu H, Qi W, Anderson J, Henry SC, Hesse RA, Richt JA, Ma W (2012) Emergence of novel reassortant H3N2 swine influenza viruses with the 2009 pandemic H1N1 genes in the United States. Arch Virol 157:555-562

26. Bowman AS, Workman JD, Nolting JM, Nelson SW, Slemons RD (2014) Exploration of risk factors contributing to the presence of influenza A virus in swine at agricultural fairs. Emerg Microbes Infect 3:e5

27. World Health Organization (2019) Antigenic and genetic characteristics of zoonotic influenza viruses and development of candidate vaccine viruses for pandemic preparedness. Wkly Epidemiol Rec 94:151-160

28. Chou YY, Albrecht RA, Pica N, Lowen AC, Richt JA, Garcia-Sastre A, Palese P, Hai R (2011) The M segment of the 2009 new pandemic H1N1 influenza virus is critical for its high transmission efficiency in the guinea pig model. J Virol 85:11235-11241
29. Moon H, Hong M, Kim JK, Seon B, Na W, Park SJ, An DJ, Jeoung HY, Kim DJ, Kim JM, Kim SH, Webby RJ, Webster RG, Kang BK, Song D (2015) $\mathrm{H} 3 \mathrm{~N} 2$ canine influenza virus with the matrix gene from the pandemic A/H1N1 virus: infection dynamics in dogs and ferrets. Epidemiol Infect 143:772-780

30. Cador C, Andraud M, Willem L, Rose N (2017) Control of endemic swine flu persistence in farrow-to-finish pig farms: a stochastic metapopulation modeling assessment. Vet Res 48:58

\section{Publisher's Note}

Springer Nature remains neutral with regard to jurisdictional claims in published maps and institutional affiliations.
Ready to submit your research? Choose BMC and benefit from:

- fast, convenient online submission

- thorough peer review by experienced researchers in your field

- rapid publication on acceptance

- support for research data, including large and complex data types

- gold Open Access which fosters wider collaboration and increased citations

- maximum visibility for your research: over $100 \mathrm{M}$ website views per year

At BMC, research is always in progress.

Learn more biomedcentral.com/submissions 